\title{
GREEN ALLIANCES: HOW DOES ECOPHILOSOPHY SHAPE THE STRATEGIES OF ENVIRONMENTAL ORGANIZATIONS?
}

\author{
Alice Comi \\ University of Reading \\ Design Innovation Research Centre \\ 216 Engineering Building, Reading RG6 6AY, UK \\ a.comi@reading.ac.uk
}

\section{Francesco Lurati}

Università della Svizzera italiana (USI)

Institute of Marketing and Communication Management (IMCA)

Via G. Buffi 13, CH-6904 Lugano, Switzerland

francesco.lurati@usi.ch

\author{
Alessandra Zamparini \\ Università della Svizzera italiana (USI) \\ Institute of Marketing and Communication Management (IMCA) \\ Via G. Buffi 13, CH-6904 Lugano, Switzerland \\ alessandra.zamparini@usi.ch
}

This is the Authors' accepted manuscript for self-archiving purposes. Please refer to the final publication on Springer's website for pages and citation. The final publication is available on: http://link.springer.com/article/10.1007/s11266-014-9478-6

Running Head: How does Ecophilosophy Shape Green Alliances?

Acknowledgments: The Authors acknowledge the input of members of Greenpeace and WWF. 


\title{
GREEN ALLIANCES: HOW DOES ECOPHILOSOPHY SHAPE THE STRATEGIES OF ENVIRONMENTAL ORGANIZATIONS?
}

\begin{abstract}
The relationship between environmental organizations and the corporate sector has gradually shifted toward the collaborative end, resulting in a broad array of "green alliances". In this paper, we focus on the strategies whereby environmental organizations seek to collaborate with private companies. In particular, we explore whether the ecophilosophy of an environmental organization - i.e., a set of values, attitudes, and beliefs about the natural environmentinfluences the selection of collaborative strategies. To address this question, we conducted two case studies of environmental organizations with a diverse ecophilosophy—namely, Greenpeace and WWF. In the cases, we covered a broad spectrum of collaborative strategies while also taking into account contextual factors with a possible influence on strategy selection. Building on our findings, we argue that ecophilosophy drives the selection of collaborative strategies and at the same time provides the lenses through which environmental organizations make sense of their operating context. We conclude by discussing the implications of our findings and by suggesting directions for future research on environmentalist-business collaboration.
\end{abstract}

Keywords: environmental organizations; collaborative strategies; ecophilosophy; Greenpeace; WWF 


\section{INTRODUCTION}

As sustainable development entered the political agenda, the relationship between environmental organizations and the corporate sector has gradually shifted toward the collaborative end. Since the sustainability paradigm provided an integrated framework for looking at economic, ecological, and social problems, the long-standing adversaries began to join forces in search for viable solutions (Murphy and Bendell 1997). Although adversarial relationships continue to arise (Rehbein, Waddock and Graves 2004; den Hond and de Bakker 2007; Zietsma and Winn 2007), anecdotal evidence suggests an increase in the number and scope of "green alliances" (Milne, Iyer and Gooding-Williams 1996; Crane 1998a; Stafford and Hartman 1998; Parker and Selsky 2004; Ählström and Sjöström 2005; Van Huijstee, Francken and Leroy 2007; van Huijstee and Glasbergen 2008; van Huijstee and Glasbergen 2010; Austin and Seitanidi 2012).

This collaborative turn is receiving increasing attention in studies of both business and nonprofit organizations, with a range of theoretical perspectives being brought to bear on the constitution of green alliances. A promising stream of literature suggests considering the "reverse side" of stakeholder theory-i.e., to examine the perspective of the environmental stakeholder seeking to influence a target company (Clair, Milliman and Mitroff 1995; Turcotte 1995; Pleuune 1997; Frooman 1999; Frooman and Murrell 2005; Hendry 2005; Henriques and Sharma 2005; Hendry 2006; Zietsma and Winn 2007; van Huijstee and Glasbergen 2010).

From this perspective, Phillips (2002) first introduced the term "corporate engagement" to indicate the practices — either adversarial or collaborative — by which a non-governmental organization seeks to engage with a private company. Hendry (2006) developed a model of corporate targeting by examining which factors lead an environmental organization to take aim at 
a particular firm. She suggested that environmental organizations first select an engagement strategy that is adversarial or collaborative in nature and subsequently identify a corporate target which is consistent with that engagement strategy. Clair et al. (1995) focused on the collaborative side of the engagement continuum and advanced propositions to explain why an environmental organization may join forces with a private company. They suggested that the ecophilosophy of the environmental organization and the characteristics of the prospect partner are both antecedents of collaborative engagement.

Like Clair et al. (1995), most scholars have built on the assumption that an anthropocentric (moderate) ecophilosophy paves the way to collaborative engagement, whereas an ecocentric (radical) ecophilosophy leads to adversarial targeting (Naess 1973; Mitchell, Mertig and Dunlap 1992; Hartman and Stafford 1997; Elkington and Fennell 1998; Winston 2002; Switzer 2004). However, such an assumption is called into question as the collaborative turn extends also to ecocentric organizations (Heap 2000; Stafford, Polonsky and Hartman 2000; den Hond and de Bakker 2007). Moreover, collaborative engagement is not uniform but rather takes different forms - ranging from preliminary to transformational collaborations concerned with reforming business operations. Such collaborative strategies involve different degrees of intensity-in terms of mutual obligation, commitment and closeness between the parties in the relationship. The linkage between ecophilosophy and collaborative engagement thus needs to be explored at a deeper level, while also taking into consideration the full range of collaborative strategies.

In this paper, we address the question of whether the ecophilosophical orientation influences the environmental organization's selection of collaborative strategies for corporate engagement. In particular, we examine the importance of ecophilosophy as compared to other 
factors with a likely influence on strategy choices, such as the characteristics of the prospect partner and the environmental issue at hand. While the current literature has discussed ecophilosophy with regard to both adversarial and collaborative strategies, we focus on the collaborative end. By so doing, we provide deeper insights into the influence of ecophilosophy, moving beyond the dichotomy between confrontation and collaboration.

To address our research question, we conducted two case studies, comparing the collaborative strategies undertaken by environmental organizations with a different ecophilosophy-namely, Greenpeace and WWF. Building upon the findings of our case studies, we argue that ecophilosophy drives the selection of collaborative strategies; with anthropocentrism (ecocentrism) leading to the selection of high-intensity (low-intensity) strategies. Furthermore, ecophilosophy provides the lenses through which environmental organizations make sense of contextual factors such as the environmental issue at hand and the characteristics of the corporate target. In turn, perceptions of contextual factors contribute to influence strategy selection, mostly by reinforcing the association between anthropocentrism (ecocentrism) and high-intensity (low-intensity) collaboration strategies.

We structure our paper as follows: In the next section, we review the literature on the influence of ecophilosophy — and contextual factors — on the engagement strategies of environmental organizations. We then take a closer look at the collaborative side of the relationship, by introducing a typology where collaborative strategies are organized along a continuum ranging from high to low intensity. After introducing the methodology used to design our case studies, we outline Greenpeace and WWF's relationship with the corporate sector, and discuss examples of the collaborative strategies sought after by the two environmental 
organizations. We conclude by elaborating on the implications of our findings, and by suggesting directions for future research in the area of business-environmentalist collaboration.

\section{INFLUENCE OF ECOPHILOSOPHY ON STRATEGY SELECTION}

Ecophilosophy is the founding ideology of an environmental organization, reflecting a set of values, attitudes, and beliefs about the natural environment and the relationship between man and nature (Fox 1994; Clair et al. 1995; Pleuune 1997; Sinha 1998). The basic focus of ecophilosophy is expressed along a continuum ranging from a purely anthropocentric to a purely ecocentric perspective. On the one hand, the anthropocentric perspective emphasizes the instrumental value of nature, suggesting that ecological sustainability is functional for ensuring the continuity of humankind. On the other hand, the ecocentric perspective underscores the intrinsic value of nature, advancing the view that every living thing is endowed with an equal right to share the wealth of the planet.

Although the literature consistently indicates that ecophilosophy is central to the identity of environmental organizations, diverse views can be distinguished as to the influence of ecophilosophy in shaping their engagement strategies (Pleuune 1997). Some scholars suggest that the ecophilosophy drives the strategy, while others suggest that the strategy is heavily dependent on the external context of the environmental organization. Among the contextual factors that influence strategy selection, scholars have consistently indicated i) the profile of the corporate target and ii) the organization of the problem domain. The first encompasses the organizational and environmental characteristics of the target company (Clair et al., 1995; Hendry, 2005, 2006). The second refers to the degree of clarity about the causes of the problem at hand and the consensus about which stakeholders should have a voice in the debate (Trist 1983; Gray and Hay 1986; Westley and Vredenburg 1991). In the following section, we review the literature debate 
on the influence of ecophilosophy - and contextual factors - in orienting the engagement strategy of environmental organizations. As discussed below, we identified three main positions — which we labeled as the centralist, relativist, and marginalist views of ecophilosophy.

\section{Centralist View of Ecophilosophy}

A first literature stream suggests that the selection of engagement strategies depends almost entirely on the ecophilosophical orientation of the environmental organization (Naess 1973; Mitchell et al. 1992; Hartman and Stafford 1997; Elkington and Fennell 1998; Dalton, Recchia and Rohrschneider 2003; Switzer 2004). This literature stream advances a dichotomous view, suggesting that anthropocentric organizations resort to collaborative methods whereas ecocentric organizations favor adversarial methods. In this perspective, ecophilosophy and strategy are strictly intertwined and they both are stable characteristics of an environmental organization. Such an assumption can be found for example in Hartman and Stafford (1997), who distinguish eco-activists and market liberals based on their ecophilosophy and engagement strategies. Yet this perspective fails to account for the possibility that other factors, such as for example the characteristics of the corporate target, may contribute to influencing an environmental organization's selection of engagement strategies. Furthermore, this literature stream focuses almost exclusively on the extreme poles of the ecophilosophical spectrum. The middle ground between anthropocentrism and ecocentrism is largely unexplored, and the question of how ecophilosophical nuances shape collaborative engagement remains unaddressed.

\section{Relativist View of Ecophilosophy}

A second literature stream disentangles the ecophilosophical orientation and the engagement strategy (Jamison, Eyerman, Cramer and Læssoee ; Norton 1991; Turcotte 1995; 
Meyer 2004; den Hond and de Bakker 2007; O' Brien 2010). The ecophilosophy provides the rationale for addressing an ecological issue whereas the strategy consists of the actions that the environmental organization undertakes to address such an issue. From this perspective, the ecophilosophy does shape the attitude toward the corporate sector, but contextual conditions intervene to influence the engagement strategy. The ecophilosophy is therefore a stable characteristic of the environmental organization whereas the engagement strategy varies depending on the context. Compared to the centralist view, this perspective has the merit to account for unexpected patterns of corporate engagement observed in empirical studies of environmental organizations. For example, Stafford et al. (2000) found that radical-wing organizations may on occasion cooperate with the corporate sector to take advantage of opportunities emerging in their operating context. Similarly, Turcotte (1995) found that environmental organizations may simultaneously resort to adversarial and collaborative engagement to accelerate progress in corporate sustainability.

\section{Marginalist View of Ecophilosophy}

A third literature stream suggests that contextual conditions are likely to exert a prevailing influence over the engagement strategy (Westley and Vredenburg 1991; Lober 1997; Pleuune 1997). For example, Pleuune (1997) found that the strategies of environmental organizationseither adversarial or collaborative - are to a large extent determined by the dominant framing of the problem in society. Similarly, Westley and Vredenburg (1991) proposed that the organization of the problem domain drives the selection among alternative strategies for collaborative engagement. When the problem domain is underorganized, conflict is diffused, non-specific, and unstructured; as a result, environmental organizations are likely to select covert and incremental strategies for collaborative engagement. On the contrary, an organized problem domain lays the 
foundation for the emergence of close partnerships, where domain stakeholders join forces to solve a commonly understood problem. By suggesting that the strategy is formulated in interaction with the problem domain, this perspective brings the advantage of seeing the environmental organization as embedded in a broader context. Moreover, this literature stream has taken a closer look at the collaborative side of the engagement continuum by attempting to associate contextual factors with diverse collaborative strategies. However, this perspective seems to ignore the suggestion that ideological discourses play a central role in shaping the strategies of activist groups (den Hond and de Bakker 2007).

While providing interesting insights, the reviewed literature is not exhaustive in regard to the influence of ecophilosophy on the engagement strategies of environmental organizations. On the one hand, the centralist and relativist views have recognized the influence of ecophilosophy on corporate engagement, but limited the appreciation of engagement strategies to a simplistic distinction between collaborative and adversarial. On the other hand, the marginalist view has advanced a more nuanced understanding of collaborative strategies but largely neglected the ecophilosophical component.

In the remainder of the paper, we will address the following research questions: Does the ecophilosophical orientation shape the choice among alternative strategies for collaborative engagement? Do contextual factors intervene to influence the selection of collaborative strategies? To address these questions, we will first take a closer look at the different strategies by which environmental organizations seek to engage in a collaborative relationship with the corporate sector. 


\section{COLLABORATIVE STRATEGIES FOR CORPORATE ENGAGEMENT}

In this section, we present a typology ${ }^{\mathrm{a}}$ in which collaborative strategies are distributed along a continuum ranging from a lower to a higher degree of collaboration intensity (Figure 1). Collaboration intensity refers to the degree of mutual obligation, commitment and closeness between the parties in the relationship (Westley and Vredenbrug 1991). Low-intensity collaboration implies loose ties, whereas high-intensity collaboration requires the parties to commit substantial resources for the constitution of a communal enterprise. In the next paragraphs, we describe the collaborative strategies, starting from the left side of the continuum. We also indicate the contextual factors under which each strategy is expected to occur, whenever such information is available in the literature.

Insert Figure 1 about here

Strategic bridging is a preliminary form of collaboration in which an environmental organization takes the role of a bridge to connect previously separate stakeholders into a dialogue (Brown 1991; Westley and Vredenburg 1991; Sharma, Vredenburg and Westley 1994; Stafford et al. 2000; Garcia and Vredenburg 2003; Lertzman, Garcia and Vredenburg 2009). For example, in the 1990s Pollution Probe attempted to create a bridge between environmental organizations and the retail industry, by articulating a vision for the then-emerging domain of sustainable consumption (Westley and Vredenburg 1991). Westley and Vredenburg (1991) proposed that strategic bridging occurs when the boundaries of the problem domain are in dispute and domain stakeholders are unwilling to collaborate on their own initiative. In this context, the bridging 
organization lays the ground for future collaboration, by advancing the articulation of the problem domain and establishing norms for interaction (Brown 1991).

The stakeholder approach (Turcotte 1995; Hendry 2004; Hendry 2005; Hendry 2006) is an instrumental form of collaboration, where the environmental organization enlists the support of corporate allies to increase pressure over a target company. The corporate allies are strategically selected among stakeholders, such as customers, suppliers, and shareholders, who control resources of vital importance for the corporate target (Hendry 2006). As the collaborative engagement is functional to constrain the corporate target, the stakeholder approach is a "mixed zone" between collaboration and confrontation (Turcotte 1995). According to Turcotte (1995), the stakeholder approach is most likely to occur on the background of a turbulent environment, where domain stakeholders tend to accuse each other for liability in ecological degradation. Indeed, a conflicting and under-organized problem domain provides an environmental organization with greater space of maneuver to play off corporate stakeholders against the target.

A marketing agreement (e.g., corporate sponsorship, product licensing, product endorsement) is a transactional collaboration in which the partners cooperate to achieve reciprocal advantages from a marketing initiative (Mendleson and Polonsky 1995; Menon and Menon 1997; Crane 1998b; Stafford and Hartman 1998). According to Heap (2000) and Stafford and Hartman (1998), an environmental organization is more likely to resort to marketing agreements when the corporate partner presents a positive record of environmental performance. Since marketing agreements do not provide the possibility to revise corporate operations, an environmental organization may prefer avoiding associations with a company liable of ecological degradation.

A task force or (multi-stakeholder) roundtable is a consultative form of collaboration in which environmental organizations and private companies - often together with other 
stakeholders_-gather to address an ecological problem (Lober 1997; Stafford and Hartman 1998;

Turcotte and Pasquero 2001; Calton and Payne 2003; Cummins 2004; Poncelet 2004; van

Huijstee and Glasbergen 2008). By leveraging the expertise of the environmental partner, the task force develops recommendations for the greening of business practices. However, the implementation of the task force recommendations is not binding on corporate partners.

A systems alliance is a transformational relationship in which the environmental organization assists the corporate partner in reforming its business operations toward a sustainable end (Clair et al. 1995; Stafford and Hartman 1996; Crane 1998b; Stafford and Hartman 1998; Livesey 1999). Compared to task forces, systems alliances are designed for action, present a longer-term orientation, and entail more comprehensive relationships between the environmental and the corporate partners.

\section{RESEARCH METHODOLOGY}

The case study method seems particularly appropriate for understanding the influence of ecophilosophy on the collaborative strategies whereby environmental organizations engage with the corporate sector. First, research on collaborative engagement is still in its early stages and the influence of ecophilosophy has not yet been systematically explored. Second, our research question requires analytical deepness to account for the contextual factors surrounding strategy selection. As suggested by Yin (1994, p. 13), the case study method enables exploring "a contemporary phenomenon within its real-life context, especially when the boundaries between phenomenon and context are not clearly evident".

In order to account for the influence of ecophilosophy on strategy selection, we chose the cases of two environmental organizations with a diverse ecophilosophical orientation-Greenpeace and WWF. Greenpeace is situated toward the ecocentric end of the 
ecophilosophical spectrum, because of its tendency to emphasize a deep connection to the natural environment. On the contrary, WWF embraces an anthropocentric ecophilosophy whereby the conservation of natural resources is functional to ensure the well-being and survival of humanity. While presenting differences in their ecophilosophical orientation, Greenpeace and WWF are comparable as regards their organizational size and international presence. This similarity enables ruling out alternative factors — such as differences in budget or professionalization — that may intervene to influence strategy choices (Frooman and Murrell 2005; Nicholson-Crotty 2009). As shown in the Appendix, the case studies have been built using multiple sources of evidence (i.e., websites, documents, and in-depth interviews), allowing for the development of convergent lines of inquiry (Yin 1994). We structured our research in three phases: exploration, deepening, and analysis. In the exploration phase, we analyzed documentary sources (brochures, letters, presentations, press releases, and reports) to understand the ecophilosophical principles and engagement strategies of Greenpeace and WWF. In so doing, we identified examples of their collaboration strategies (Tables I-II), spanning the entire continuum from low- to high-intensity collaboration. Such examples have been selected for being typical of the engagement strategies of the two environmental organizations, and/or for representing a milestone in their relationship with the corporate sector.

During the deepening phase, we conducted semi-structured in-depth interviews with senior staff members of Greenpeace and WWF who were involved in the selected examples of collaborative strategies (Tables I-II). The interviews focused on the rationale and the factors behind the selection of the diverse strategies. For each collaboration example, we integrated evidence from other publications and reports, thereby including second-order data among our sources of evidence. We also searched newspaper articles via Lexis Nexis to gather further information on contextual factors, and to gain an understanding of the corporate perspective. 
In the analysis phase, we integrated the data collected in order to map out the relationships between ecophilosophy, context, and strategy. For each case study, we arranged the data in a tabular format (Miles and Huberman 1994) displaying the constructs of interests (i.e., ecophilosophy, context, and strategy). Afterwards, a case study report was written, through a process of constant iteration between the data and the conceptualization of the findings. Whereas the first author collected the data, the analysis phase involved dialogue within the research team, with the case study reports being circulated, discussed and refined in several rounds of revisions.

\section{GREENPEACE AND WWF'S ENGAGEMENT STRATEGIES}

\section{Greenpeace}

Greenpeace defines itself as "an independent, campaigning organization that uses direct action and creative confrontation to expose global environmental problems, and to force solutions for a green and peaceful future" (www.greenpeace.org). Direct action can take diverse forms, such as confronting a whaling ship on the high seas, blocking the shipment of radioactive material, or scaling the buildings of a multinational company. The various tactics combine into a "creative confrontation", whereby Greenpeace forces governments and corporations to the negotiating table (Greenpeace 2006a).

While keeping true to the founding values of direct action, Greenpeace has gradually turned toward dialogue with private companies, with a view of exploiting their increasing influence on the global economy (Tindale 2002). Launched in 1992, the Greenfreeze Campaign-intended to bridge the vision of the Montreal Protocol to the refrigeration industry-marked the onset of Greenpeace's engagement with the corporate sector. Besides confrontation with leading refrigeration companies, the campaign involved a corporate 
partnership with an East German appliance maker, Foron. The partners worked together to develop a commercially viable alternative to chlorofluorocarbons, at the time used in most refrigerator and cooling appliances. Based on an ecologically sound butane-propane mixture, Foron's Greenfreeze was first sold on the German market, and subsequently set the standard for the refrigeration industry on a global scale.The Greenfreeze Campaign provided the backbone for the development of Greenpeace's Market Solutions and Corporate Campaigns, aimed to catalyze solutions to global concerns through engagement with corporations and consumer markets (Lohbeck 2004).

The novel strategy provided Greenpeace with the possibility of abandoning the "gloom and doom" undertones of many environmental organizations, which perpetrate a sense of helplessness and fatigue. Yet the Market Solutions and Corporate Campaigns involved the risk of jeopardizing Greenpeace's position, by calling into question its independence from the corporate sector (Hartman and Stafford 2006). The international director Paul Guilding intervened to assure that the novel strategy merely extended the adversarial approach, with a view of "advancing environmentalism by interfering in markets" (Stafford et al. 2000, p. 131). The combination of adversarial and collaborative tactics gave way to an "inside-out" strategy: Inside the boardrooms, Greenpeace was joining forces with private companies to advance the sustainability of marketplaces. Outside the boardrooms, Greenpeace was keeping up a steady base of protestors to ensure that corporate partners followed through on the negotiated agreements (Hartman and Stafford 2006).

Since the engagement strategy of Greenpeace occurs in a mixed zone between collaboration and confrontation, representative members avoid talking about a collaborative relationship with the corporate sector. Greenpeace's engagement strategy consists essentially of advocating for green technologies; and of endorsing corporate progress toward sustainability (W. 
Lohbeck, interview data, 18 December 2007; Tindale 2002). Consistently with its founding values, Greenpeace tends to forge collaborative relationships of a low to moderate intensity (i.e., strategic bridging, stakeholder approach, marketing agreements).

Table 1 illustrates three examples of collaboration strategies sought after by Greenpeace: the Greenfreeze Campaign (strategic bridging), the Kleercut Campaign (stakeholder approach), and a range of marketing agreements for green merchandise. While these examples are typical of Greenpeace's engagement strategy, the systems alliance with Foron-initiated on the background of the Greenfreeze Campaign-involved an exceptionally high degree of mutual commitment.

Insert Table I about here

\section{WWF}

WWF (World Wide Fund for Nature) considers corporate engagement as being central to the mission of reversing the ecological crisis and ensuring the well-being of humanity. According to Jean-Paul Jeanrenaud, Corporate Relations Director of WWF International, the massive influence of the private sector can be directed to shape the ecological policy of governments and to advance sustainable consumption in the marketplace. Furthermore, reduction in the footprint of multinational corporations can make a difference to WWF's agenda of tackling climate warming, phasing out toxic chemicals, and conserving natural resources (Jeanrenaud 2007b).

In advocating for corporate responsibility, WWF embraces a paradigm of market-based environmentalism, which calls attention to the inherent interconnection between ecologic, 
economic, and social objectives. WWF envisages a future in which the private sector makes a positive contribution to the welfare of nature and society by selling solutions designed to tackle the legacy left by decades of unsustainable consumption. A private company should therefore internalize the environmental cost of production operations and implement a business model centered on the creation of value for society (Jeanrenaud and Boulos 2005).

In order to reform the corporate sector, WWF uses both "pushing" and "pulling" strategies. On the one hand, WWF pushes companies by resorting to tactics such as lobbying campaigns, media advocacy, and shareholder resolutions. On the other hand, WWF pulls the corporate sector by forming innovative partnerships for the integration of profitability and sustainability. As stated in the institutional mission, "WWF doesn't shy away from confrontation, but promotes constructive interactions to create awareness, spread ideas, and stimulate discussions" (WWF International 2004).

WWF collaborates with the corporate sector through a variety of "green alliances", ranging from fundraising relationships to conservation partnerships and multi-stakeholder roundtables. The partnership types are conceived as diverse layers of a ladder representing an ideal course whereby collaboration progresses from an exchange relationship toward a strategic association centered on the paradigm of sustainable development (Jeanrenaud and Boulos 2003). Therefore, WWF promotes a comprehensive approach to corporate responsibility and manages for the collaborative relationship to undergo a progressive deepening in function, scope, and strategic rationale (Jeanrenaud 2007a; Manager Corporate Marketing, WWF International, interview data, 30 November 2007).

While delivering considerable advantages, collaborative engagement exposes WWF to the risk of losing its moral high ground and reputation. WWF has therefore put in place engagement guidelines (WWF UK 2006): As a primary condition, WWF enters into a partnership only if the 
engagement provides a "strategic fit" with respect to its conservation mission. As a further condition, the corporate partner should prove to be best in class, or operate in a sector which imposes a minimal or negligible impact on the environment. Yet WWF may also engage companies with a debatable ecological track, provided that the partnership program is designed to realize substantial changes in corporate operations (Jeanrenaud and Boulos 2003).

Table 2 illustrates three examples of the collaborative engagements sought after by WWF: i) a licensing agreement for a clothing collection, ii) a multi-stakeholder roundtable to advance sustainability in cotton cultivation and iii) a systems alliance to improve the environmental record of Lafarge, the world's largest cement manufacturer. While these collaborations are typical of WWF's engagement strategy, the systems alliance with Lafarge involved confrontation and tension.

Insert Table II about here

\section{CASE STUDIES DISCUSSION}

\section{The Influence of Ecophilosophy on the Selection and Interpretation of Collaborative}

\section{Strategies}

Our case studies suggest that ecophilosophy orients the selection of collaborative strategies, as both Greenpeace and WWF selected collaborative strategies that were consistent with their ecophilosophy. While WWF engaged in highly intense collaborations such as task forces or systems alliances, Greenpeace favored collaborative strategies of a preliminary or instrumental nature. Therefore, looking at the ecophilosophical orientation provides the foundation for understanding which collaborative strategies an environmental organization is 
likely to select. In this regard, we confirm den Hond and de Bakker's (2007) suggestion that ideology offers a useful link to the repertoire of strategies that activist groups consider as legitimate and suitable.

Yet environmental organizations occasionally resort to strategies that appear at odds with their ecophilosophy. On the background of the Greenfreeze campaign, Greenpeace engaged in a systems alliance with Foron, and assisted the corporate partner in conforming its operations to sustainability standards. A disconnect between the ecophilosophy and the strategy of environmental organizations was observed also in prior studies (Turcotte 1995; Heap 2000; Stafford et al. 2000; Hartman and Stafford 2006). While confirming that the linkage between ecophilosophy and strategy is not of a deterministic nature, this finding raises further questionshow do environmental organizations manage to maintain consistency with their ecophilosophy when selecting "atypical" strategies?

In order to address this question, we looked at how representative members of Greenpeace and WWF account for, and interpret the strategies chosen for engaging with their corporate targets. Interestingly, when they select an "atypical" strategy for collaborative engagement, environmental organizations reframe such a strategy in way to reaffirm their ecophilosophical position. For example, Greenpeace representatives refused to describe their relationship with Foron in terms of a systems alliance and preferred speaking of a "technical partnership". In the words of Wolfgang Lohbeck, Head of the Greenfreeze Campaign, Greenpeace's relationship with companies is not of a collaborative nature. In the case of Foron I would concede we made a step beyond the limit... Still it was not a collaborative relationship, because Greenpeace was neither involved in the production process, nor took part of the image of the company. I would say it was 
a technical partnership, because we wanted to establish a standard technology on the market (W. Lohbeck, interview data, 18 December 2007).

In effect Greenpeace refused to serve Foron's interest, and distributed the Greenfreeze drawings to multiple appliance makers - in Europe as well as in developing countries. While Greenpeace concentrated on the global Greenfreeze Campaign, Foron declared bankruptcy, lacking the financial resources and marketing know-how to compete with leading companies. As further explained by Lohbeck,

We did not ask supporters to buy a Foron fridge, but rather to buy a Greenfreeze... Foron did not understand the difference, [and this created tension in the relationship]. We had hard times explaining them that we endorse technologies and not companies.

And of course we did not let Foron patent the Greenfreeze, because we wanted the technology to spread all over the world. We were happy with Siemens-Bosch adopting the technology, although this meant that Foron was no longer the unique seller of the Greenfreeze.

The ecophilosophical orientation also leads environmental organizations to make certain features of their collaborative engagement more or less prominent, in ways that are consistent with their ecophilosophical beliefs. In the Kleercut Campaign, Greenpeace emphasized the adversarial side of the stakeholder approach and considered corporate allies as mere pawns in the campaign against Kimberly Clark. Whereas the stakeholder approach is positioned in the "mixed zone" between collaboration and confrontation (Turcotte 1995), Greenpeace shifts the strategy 
toward the confrontation end, in line with its adversarial view of the corporate world. To mention another example, the systems alliance with Lafarge involved confrontation around a quarry project, yet WWF emphasized the collaborative side of the engagement, speaking of a "tough dialogue.” According to Jean-Paul Jeanrenaud, Corporate Relations Director of WWF International,

Throughout the partnership, there have been periods of difficulty and areas of disagreement. We have however been able to overcome these through mutual respect, by being transparent and willing to discuss, and by taking on the role of a 'critical friend' (Lafarge and WWF 2011).

Since ecophilosophy shapes the perception of strategy, it follows that the same strategy assumes diverse connotations, depending on the ecophilosophical orientation of the environmental organization adopting such a strategy. Transactional collaborations like marketing agreements are interpreted and executed in different ways by environmental organizations with a diverse ecophilosophy_-such as Greenpeace and WWF. While WWF interprets marketing agreements as the first step in a collaborative journey, Greenpeace adapts marketing agreements in such a way as to avoid close ties with its licensed manufacturers. For example, the disclaimer on Greenpeace's Green Gifts website reads “Greenpeace does not have overview of production processes at CaféPress. We are in dialogue with CaféPress to improve the environmental quality of their product line-you can contribute to this effort by writing to CaféPress and asking them to introduce more organic products, and to drop items such as bumper stickers made from PVC" (www.greenpeace.org). Furthermore, Greenpeace reframes product endorsement as an attempt to support the technology built in the product, rather than the product itself. In the words of Lohbeck, 
At times we endorse a sustainable technology [...] but in no single case we endorse the company or the product as such.

For the products in our catalogue, we guarantee quality on certain aspectssaying, 'this product is made of sustainable cotton', or 'is free from PVC'-but we never endorse the company behind the product (W. Lohbeck, interview data, 18 December 2007).

\section{The Influence of Ecophilosophy on the Perception of Contextual Factors}

Our case studies shed further light on the relationship between ecophilosophy and contextual factors (i.e., the articulation of the problem domain and the characteristics of the corporate target). Whereas current literature has presented contextual factors as objective properties of the external context of environmental organizations (Westley and Vredenburg 1991; Turcotte 1995; Pleuune 1997), we propose conceiving of contextual factors as internal perceptions shaped by the ecophilosophical perspective of environmental organizations. The different perceptions of the problem domain articulation are evident in the interview accounts of representative members of both Greenpeace and WWF. While WWF generally recognizes the inherent complexity of problem domains, Greenpeace tends to downplay scientific complexity in favor of a stricter approach to environmental protection. On several occasions, Greenpeace interviewees blamed corporate actors for representing the problem domain as being inextricably complicated, in an attempt to delegitimize well-established environmental standards. For example, Lohbeck declared that the refrigerant industry raised undue concerns about the safety of the butane-propane mixture embedded in the Greenfreeze technology. In a similar way, Lindsey Allen, Forest Campaigner in the Kleercut Campaign, suggested that the forest industry 
deliberately covered up scientific evidence and framed the problem domain in such a way as to confuse relevant stakeholders:

Just as we've seen with the issue of climate change, the industry tries to create a debate [around certification schemes] and then work to confuse the conversation instead of defining the difference in practices [....] By creating a new certification with unclear standards (SFI, Sustainable Forestry Initiative), the industry has attempted to limit the effectiveness of FSC [Forest Stewardship Council] ${ }^{\mathrm{b}}$. The industry is trying to complicate things to confuse people, but the science around the devastating impact of clearcuts on the ecosystem is very clear (L. Allen, interview data, 14 December 2007).

On the other hand, WWF underscores the intrinsic complexity of crop cultivation, fishing, and forestry and accordingly involves multiple stakeholders in large-scale projects to advance the articulation of these problem domains. In the words of Lise Melvin, Manager of WWF's Better Cotton Initiative,

There are good agricultural practices or better management practices, and a fair amount of material is available. It is generally understood that you need to look at soil, water, pesticides, fertilizers, and labor conditions. But when you get down to the details of how to actually deal with the problem, it becomes complex. And it's also a question of how you share that knowledge with all the farmers around the world (L. Melvin, interview data, 11 January 2008).

The ecophilosophical orientation also seems to influence the environmental organization's perception of the corporate target, especially in terms of the perceived importance of corporate 
environmental performance. On the one hand, WWF carefully evaluates the environmental track of its corporate targets in the perspective of engaging in long-term and transformational relationships (Jeanrenaud and Boulos 2003; WWF UK 2006). On the other hand, Greenpeace does not even look at the corporate environmental performance of its licensed manufacturers of green products. Similarly, corporate supporters in the campaign against Kimberly Clark were praised for taking a step forward in forest protection without undergoing any assessment of ecological performance (Greenpeace 2006c). Although apparently contradictory, Greenpeace's lack of interest in its corporate partners is consistent with the vision of having "no permanent allies or adversaries". In fact, Greenpeace does not actually consider its corporate engagement as being collaborative in nature, but rather tends to exploit corporate allies for short-term technical partnerships. As further explained by Allen,

The environmental record of corporate supporters is not under scrutiny. What we are asking for varies by campaign to campaign, and a company is only given credit on the progress they have made related to what we are asking. One of the things we are clear about is that we have no permanent friends, and no permanent enemies (L. Allen, interview data, 14 December 2007).

\section{The Influence of Perceived Contextual Factors on Strategy Selection}

Driven by ecophilosophy, the perception of contextual factors may in turn contribute to influencing the environmental organization's selection of strategies for collaborative engagement. First, the perception of the problem domain may reinforce the association between anthropocentrism (ecocentrism) and the selection of high-intensity (low-intensity) collaboration strategies. Since anthropocentric organizations perceive a need to advance the articulation of the problem domain, they are even more likely to engage in close collaboration with domain 
stakeholders. For example, WWF formed the Better Cotton Initiative to define management practices for sustainable cotton cultivation in consultation with multiple stakeholders. On the contrary, ecocentric organizations like Greenpeace perceive problem domains as being inherently articulated, and hence are less likely to engage in such multi-stakeholder collaborations.

Second, the perception of corporate environmental performance seems to orient the collaborative strategies of anthropocentric organizations, with negative perceptions leading to the avoidance of low-intensity strategies. For example, WWF refused to sign a marketing agreement with Lafarge - a large carbon emitter - but proposed the constitution of a systems alliance to reduce the company's footprint on the natural environment. Doing so, WWF protected itself against the risk of negative image transfer while also pushing the corporate target in the direction of a highly intense collaboration. On the contrary, we observed that ecocentric organizations such as Greenpeace perceive corporate environmental performance as being relatively unimportant for their collaborative engagement. As follows, they are not bound by considerations of the environmental performance of the corporate target in selecting collaborative strategies. In effect, Greenpeace adopted different strategies to bring about change in unsustainable companies, resorting to a stakeholder approach against Kimberly Clark while forming a systems alliance with Foron. Yet both companies had a negative environmental record, with Kimberly Clark sourcing timber from ancient rainforest and Foron lacking any compliance to sustainability standards. In this regard, ecocentric organizations are able to span the collaboration continuum by assigning little or no importance to their corporate partners.

In summary, our case studies suggest that ecophilosophy influences the selection and interpretation of collaborative strategies: Anthropocentric organizations favor high-intensity strategies, in line with a developmental view of collaboration. On the contrary, ecocentric 
organizations favor low-intensity strategies and view their corporate engagement as being instrumental in nature. While environmental organizations gravitate toward either the high- or low-intensity end of the collaboration continuum, they are able to reframe an "atypical" strategy in such a way as to reaffirm their ecophilosophical principles. Therefore, environmental organizations are able to appropriate diverse strategies, and load the same strategy with diverse meanings in light of their ecophilosophical perspective.

Furthermore, ecophilosophy acts as lenses through which environmental organizations make sense of contextual factors such as the articulation of the problem domain and the characteristics of the corporate target. Unlike their ecocentric counterparts, anthropocentric organizations perceive problem domains as being under-organized, and view corporate stakeholders as valuable allies in the quest to advance their articulation. The perceived articulation of the problem domain, in turn, may contribute to reinforcing an environmental organization's preference for either high or low-intensity collaborations. Moreover, the perception of negative corporate environmental performance further orients the strategies of anthropocentric organizations toward the high-end of the collaboration intensity continuum (whereas ecocentric organizations assign little or no value to the characteristics of their corporate target).

Therefore, the influence of ecophilosophy on strategy selection follows two paths, one direct and the other indirect - through the perception of the external context (i.e., problem domain and corporate target characteristics). Interestingly, ecocentric organizations are able to span the entire collaboration continuum, by emphasizing the instrumental purpose of their engagement and portraying their partners as mere pawns in the quest against ecological degradation. 


\section{CONCLUSION}

In this paper, we explored the influence of ecophilosophy — and contextual factors - on the collaborative strategies whereby environmental organizations agree or seek to engage with the corporate sector. We conducted two case studies of environmental organizations with diverse ecophilosophies (Greenpeace and WWF), with each case covering three examples of collaborative strategies. Drawing on the findings of our case studies, we explained the relationships between ecophilosophical orientation, contextual factors, and strategy selection.

Our work provides a twofold contribution to the literature on environmentalist-business collaboration. First, we shed light on the disconnect between ecophilosophy and strategy observed also in prior studies (Turcotte 1995, Stafford et al. 2000). Since the meaning of strategy is framed by the ecophilosophical perspective, environmental organizations are able to appropriate virtually any strategy along the collaboration continuum. Since the external context is defined through the ecophilosophy lenses, environmental organizations may select different strategies based on the same problem domain and toward the same corporate actor. Second, by discussing the role of perceived contextual factors, we contribute to bridging the gap between the so-called "centralist" and "marginalist" views of ecophilosophy. While arguing for the central role of ecophilosophy in the engagement strategy of environmental organizations, we suggest that contextual factors - conceived as internal perceptions - contribute to driving the selection among alternative choices.

Moreover, our findings suggest implications for environmental organizations. As a foremost consideration, environmental organizations should be aware of the risks involved in collaborative engagement, and be ready to address potential conflict with the corporate partner. In our case studies we observed several moments of tensions between environmental and corporate partners, making the collaborative engagement a tough dialogue. In order to avoid the risk of 
reputation loss, environmental organizations should manage to maintain consistency between their ecophilosophy and their strategies. Especially ecocentric organizations may need to legitimize their collaborative ties with the corporate sector, for example by framing their collaborative engagement as being instrumental in the pursuit of their ecophilosophical vision.

Although providing interesting insights, our qualitative study is not without limitations, and we cannot exclude that the addition of further data from other environmental organizations may lead to refinements — or modifications — of our findings. Our understanding of the role of contextual factors needs to be consolidated, for example by comparing the perceptions of an identical context on the part of environmental organizations with diverse ecophilosophies. How does the interpretation of the same context vary depending on the ecophilosophical perspective? What is the influence of such an interpretation on the selection of collaborative strategies? Future research may thus strive to establish greater confidence in our findings and simultaneously move the first steps in the direction of proposition or hypothesis development.

At a more fundamental level, we cannot exclude the possibility that other environmental organizations collaborate with the corporate sector for reasons different than the ones of Greenpeace and WWF. For example, smaller environmental organizations may just follow the lead of larger environmental organizations or join a corporate campaign to gain standing within the environmental movement. While we have focused on environmental organizations with an international scope, consideration of other types of environmental organizations may lead to a rather different picture of the relationship between ecophilosophy, context, and strategy. In the case of smaller environmental organizations, the balance would probably shift toward a higher influence of contextual factors. In fact, smaller environmental organizations may rely more on emerging opportunities than on strategic decisions, as resource constraints may reduce the range of collaborative strategies that they can actually use to target a particular company. 
In addition, the relationship between the ecophilosophy and the communication of environmental organizations deserves further attention. As discussed herein, when resorting to an “atypical" collaboration strategy, environmental organizations reframe such a strategy by reaffirming their ecophilosophical principles. An action that might undermine legitimacy is reframed in such a way as to build further legitimacy and consolidate the ideological principles of the environmental organization. Future scholars should thus explore the communication strategy, in terms of the argumentation, framing, and rhetorical devices, whereby environmental organizations legitimize their collaborative ties with the corporate sector. 


\section{REFERENCES}

Ählström, J., \& Sjöström, E. (2005). CSOs and business partnerships: Strategies for interaction. Business Strategy and the Environment, 14(4), 230-240.

Aspen Skiing Company. (2007). Letter to Thomas Falk, CEO of Kimberly Clark. Retrieved 12 October, 2013, from https://secureusa.greenpeace.org/students/kits/files/16/Aspen_Letter.pdf

Austin, J. E., \& Seitanidi, M. M. (2012). Collaborative value creation: A review of partnering between nonprofits and businesses (Part I). Nonprofit and Voluntary Sector Quarterly, 41(5), 726-758.

BCI (2007). Better Cotton Initiative. Paper presented at the Environmental Justice Foundation Round Table for Sustainable and Ethical Cotton, London, 25 April.

Brown, D. L. (1991). Bridging organizations and sustainable development. Human Relations, 44(8), 807-831.

Calton, J. M., \& Payne, S. L. (2003). Coping with paradox. Business \& Society, 42(1), 7-42.

Canada Newswire (2006). Over 650 businesses pledge not to use Kimberly Clark tissue products, 22 August.

Canada Newswire (2007). Greenpeace criticizes Kleenex manufacturer's "green" policy before AGM, 24 April.

Clair, J. A., Milliman, J., \& Mitroff, I. (1995). Clash or cooperation? Understanding environmental organizations and their relationship to business. Research in Corporate Social Performance and Policy (1), 163-193.

Crane, A. (1998a). Culture clash and mediation: Exploring the cultural dynamics of businessNGO collaboration. Greener Management International, 24, 61-76. 
Crane, A. (1998b). Exploring green alliances. Journal of Marketing Management, 14(6), 559579.

Cummins, A. (2004). The Marine Stewardship Council: A multi-stakeholder approach to sustainable fishing. Corporate Social Responsibility and Environmental Management, 11(2), 85-94.

Dalton, R. J., Recchia, S., \& Rohrschneider, R. (2003). The environmental movement and the modes of political action. Comparative Political Studies, 36(7), 743-771.

den Hond, F., \& de Bakker, F. G. A. (2007). Ideologically motivated activism: How activist groups influence corporate social change activities. Academy of Management Review, 32(3), 901-924.

Elkington, J., \& Fennell, S. (1998). Partners for sustainability. Greener Management International 24, 49-60.

Elliott, C., \& Schlaepfer, R. (2001). Understanding forest certification using the Advocacy Coalition Framework. Forest Policy and Economics, 2(3-4), 257-266.

Fox, W. (1994). Ecophilosophy and science. The Environmentalist, 14(3), 207-213.

Frooman, J. (1999). Stakeholder influence strategies. The Academy of Management Review, 24(2), 191-205.

Frooman, J., \& Murrell, A. J. (2005). Stakeholder influence strategies: The roles of structural and demographic determinants. Business and Society, 44(1), 3-31.

Garcia, P., \& Vredenburg, H. (2003). Building corporate citizenship through strategic bridging in the oil and gas industry in Latin America. Journal of Corporate Citizenship, 10, 37-49.

Giraud-Guigues, L., Jeanrenaud, J. P., \& McIntosh, A. (2004). Corporate ethics and the Harry superquarry. ECOS, Journal of the British Association of Nature Conservationists, 25(2), 45-52. 
Gray, B., \& Hay, T. (1986). Political limits to interorganizational consensus and change. Journal of Applied Behavioral Science, 22(2), 95-112.

Greenpeace. (1997). Saving the ozone layer. The Montreal Protocol and moral priorites. Position paper. Retrieved 5 April, 2008, from http://archive.greenpeace.org/ozone/greenfreeze/moral97/index.html.

Greenpeace. (2004). Greenpeace launches Kleenex "Kleercut" Campaign. Retrieved 10 January, 2008, from http://kleercut.net/en/node/48.

Greenpeace. (2006a). Annual Report 2006. Retrieved 10 January, 2008, from http://www.greenpeace.org/international/en/publications/reports/annual-report-2006/.

Greenpeace. (2006b). Chain of Lies. The truth about Kimberly Clark's use of ancient rainforests for tissue products. Retrieved 10 January, 2008, from http://www.kleercut.net/en/files/ChainofLies_final.pdf.

Greenpeace. (2006c). Forest Friendly 500 Action Kit. All you need to know to recruit forest friendly businesses. Retrieved 12 October, 2013, from http://forestfriendly500.org/files/ff_500_toolkit.pdf.

Greenpeace. (2006d). US Securities and Exchange Commission asked to investigate Kleenex's manufacturer false environmental claims. Retrieved 10 January, 2008, from http://kleercut.net/en/coastal.

Hartman, C. L., \& Stafford, E. R. (1997). Market-Based Environmentalism: Developing green marketing strategies and relationships. In D. T. Leclair \& M. Hartline (Eds.), American Marketing Association Winter Educators' Conference Proceedings (pp. 156-163). Chicago: American Marketing Association.

Hartman, C. L., \& Stafford, E. R. (2006). Chilling with Greenpeace, from the inside out. Stanford Social Innovation Review, 4(2), 54-59. 
Heap, S. (2000). NGOs Engaging with Business: A World of Difference and a Difference to the World. UK: INTRAC.

Heimer, C., Pudney, R., Jeanrenaud, J. P., Giraud-Guigues, L., \& Picard, M. (2006). Tough dialogue pays off. How Lafarge and WWF make their partnership work to help preserving the world's ecological balance. Paper presented at the conference on "Business as an Agent of World Benefit: Management Knowledge Leading Positive Change", Cleveland US, October 23-25.

Hendry, J. R. (2004). Influential environmental stakeholders: A grounded model of processes for effecting change. In S. Sharma \& M. Starik (Eds.), Stakeholders, the environment and society (pp. 62-92). Northampton, MA: Edward Elgar Publishing.

Hendry, J. R. (2005). Stakeholder Influence Strategies: An Empirical Exploration. Journal of Business Ethics, 61(1), 79-99.

Hendry, J. R. (2006). Taking aim at business: What factors lead environmental non-governmental organizations to target particular firms? Business and Society, 45(1), 47-86.

Henriques, I., \& Sharma, S. (2005). Pathways of stakeholder influence in the Canadian forestry industry. Business Strategy and the Environment, 14(6), 384-398.

Houlder, V. (2000). Inside Track: Coolants spark heated debate. Financial Times.

IFC-WWF. (2004). Better management practices for agribusiness commodities. Retrieved 13 February, 2008, from http://assets.panda.org/downloads/finalbettercottonbriefing13sep04.pdf.

IUCN, UNEP, \& WWF. (1980). World Conservation Strategy. Living resource conservation for sustainable development. Retrieved 10 January, 2008, from http://data.iucn.org/dbtwwpd/edocs/WCS-004.pdf. 
Jamison, A., Eyerman, R., Cramer, J., \& Læssoee, J. The making of the new environmental consciousness: A comparative study of the environmental movements in Sweden, Denmark, and the Netherlands. Edinburgh: Edinburgh University Press.

Jeanrenaud, J. P. (2007a). Interview on "The nature of business". Retrieved 10 January, 2008, from www.panda.org/news_facts/newsroom/on_the_ground/index.cfm?uNewsID=99800. Jeanrenaud, J. P. (2007b). One planet living and the challenge of corporate responsibility. Paper presented at the International Conference for Sustainable Conservation and Development, Romania, April 2007.

Jeanrenaud, J. P., \& Boulos, M. (2003). The challenge of cooperation: WWF and partnerships with business. Sustainable Development International, 9, 1-3.

Jeanrenaud, J. P., \& Boulos, M. (2005). One planet business: the challenge of corporate responsibility. Sustainable Development International, 16, 42-47.

Kimberly Clark. (2005). Our commitment to health and hygiene. Kimberly Clark's Sustainability Report. Retrieved 13 April, 2008, from http://www.kimberlyclark.com/pdfs/2005SustainabilityReport.pdf.

Lafarge. (2000). Lafarge and WWF: A worldwide partnership. Retrieved 11 February, 2008, from http://www.lafarge.com/wps/portal/6_2_4IxDet?WCM_GLOBAL_CONTEXT=/wps/wcm/connect/Lafarge.com/AllPR/200.

Lafarge, \& WWF. (2005). Two worlds, one planet. WWF and Lafarge partners since 2000. Retrieved 11 February, 2008, from http://www.lafarge.com/06202005publications_sustainable_development-Lafarge_and_wwf_partnership-uk.pdf.

Lafarge, \& WWF. (2011). Ten years anniversary brochure. The partnership explained in ten answers. Retrieved 22 September, 2011, from http://www.lafarge.com/07112011sustainable_development-wwf_lafarge_brochure-uk.pdf. 
Lertzman, D., Garcia, P., \& Vredenburg, H. (2009). A national oil company as social development agent. International Review of Business Research Papers, 5(5), 1-15.

Livesey, S. M. (1999). McDonald's and the Environmental Defense Fund: A case study of a green alliance. Journal of Business Communication, 36(1), 5-39.

Lober, D. J. (1997). Explaining the formation of business-environmentalist collaborations: Collaborative windows and the Paper Task Force. Policy Science, 30(1), 1-24.

Lohbeck, W. (2004). Greenfreeze: from a snowball to an industrial avalanche. Retrieved 11 February, 2008, from http://www.greenpeace.org/international/Global/international/planet2/report/2006/3/greenfreeze-from-snowball-to.pdf.

Mendleson, N., \& Polonsky, M. J. (1995). Using strategic alliances to develop credible green marketing. The Journal of Consumer Marketing, 12(2), 4-18.

Menon, A., \& Menon, A. (1997). Enviropreneurial marketing strategy: The emergence of corporate environmentalism as market strategy. Journal of Marketing, 61(1), 51-67.

Meyer, M. (2004). Organizational identity, political contexts, and SMO action: Explaining the tactical choices made by peace organizations in Israel, Northern Ireland, and South Africa. Social Movement Studies, 3(2), 167-197.

Miles, M. B., \& Huberman, A. M. (1994). Qualitative data analysis. Beverly Hills, CA: Sage. Milne, G. R., Iyer, E. S., \& Gooding-Williams, S. (1996). Environmental organization alliance relationships within and across nonprofit, business, and government sectors. Journal of Public Policy \& Marketing, 15(2), 203-215.

Mitchell, R. C., Mertig, A. G., \& Dunlap, R. E. (1992). Twenty years of environmental mobilization: Trends among national environmental organizations. In R. E. Dunlap \& A. 
G. Mertig (Eds.), American Environmentalism. The U.S. Environmental Movement, 19701990 (pp. 11-26). Philadelphia: Taylor and Francis.

Murphy, D. F., \& Bendell, J. (1997). In the Company of Partners: Business, Environmental Groups and Sustainable Development Post-Rio. Bristol, UK: Policy Press.

Naess, A. (1973). The shallow and the deep, long-range ecology movement. A summary. Inquiry, 16(1), 95-100.

Nicholson-Crotty, J. (2009). The Stages and Strategies of Advocacy Among Nonprofit Reproductive Health Providers. Nonprofit and Voluntary Sector Quarterly, 38(6), 10441053.

Norton, B. (1991). Toward unity among environmentalists. New York, NY: Oxford University Press.

O' Brien, T. (2010). Stuck in the middle: Maintaining the organizational legitimacy of the Regional Environmental Center. Voluntas: International Journal of Voluntary and Nonprofit Organizations, 21(3), 339-357.

Parker, B., \& Selsky, J. W. (2004). Interface dynamics in cause-based partnerships: An exploration of emergent culture. Nonprofit and Voluntary Sector Quarterly, 33(3), 458488.

Phillips, R. (2002). Is corporate engagement an advocacy strategy for NGOs? The Community Aid Abroad experience. Nonprofit Management and Leadership, 13(2), 123-137.

Pleuune, R. (1997). The Importance of contexts in strategies of environmental organizations with regard to climate change. Environmental Management, 21(5), 733-745.

Poncelet, E. C. (2004). Partnering for the environment: Multistakeholder collaboration in a changing world. Lanham, MD: Rowman \& Littlefield. 
Rehbein, K., Waddock, S., \& Graves, S. B. (2004). Understanding shareholder activism: Which corporations are targeted? Business \& Society, 43(3), 239-267.

Sharma, S., Vredenburg, H., \& Westley, F. (1994). Strategic bridging: A role for the multinational corporation in Third World development. Journal of Applied Behavioral Science, 30(4), 458-476.

Sinha, P. C. (1998). Green Philosophy. New Dehli: Anmol Publications.

Stafford, E. R., \& Hartman, C. L. (1996). Green Alliances: Strategic relations between businesses and environmental groups. Business Horizons, 39(2), 50-59.

Stafford, E. R., \& Hartman, C. L. (1998). Toward an Understanding of the Antecedents of Environmentalist-Business Cooperative Relations. In R. C. Goodstein \& S. B. Mackenzie (Eds.), American Marketing Association Summer Educators' Conference Proceedings (pp. 56-63). Chicago, IL: American Marketing Association.

Stafford, E. R., Polonsky, M. J., \& Hartman, C. L. (2000). Environmental NGO-business collaboration and strategic bridging: A case analysis of the Greenpeace-Foron Alliance. Business Strategy and the Environment, 9(2), 122-135.

Switzer, J. V. (2004). Environmental politics: domestic and global dimensions. Belmont, CA: Wadsworth.

Tindale, S. (2002). Greenpeace business strategy and actions. Corporate Environmental Strategy, 9(3).

Trist, E. (1983). Referent organizations and the development of inter-organizational domains. Human Relations, 36(3), 269-284.

Turcotte, M.-F. (1995). Conflict and collaboration: The interfaces between environmental organizations and business firms. Research in Corporate Social Performance and Policy (Supplement 1), 195-229. 
Turcotte, M.-F., \& Pasquero, J. (2001). The paradox of multistakeholder collaborative roundtables. The Journal of Applied Behavioral Science, 37(4), 447-464.

Van Huijstee, M., Francken, M., \& Leroy, P. (2007). Partnerships for sustainable development: A review of current literature. Environmental Sciences, 4(2), 75-89.

van Huijstee, M., \& Glasbergen, P. (2008). The practice of stakeholder dialogue between multinationals and NGOs. Corporate Social Responsibility and Environmental Management, 15(5), 298-310.

van Huijstee, M., \& Glasbergen, P. (2010). NGOs moving business: An analysis of contrasting strategies. Business \& Society, 49(4), 591-618.

Westley, F., \& Vredenburg, H. (1991). Strategic bridging: The collaboration between environmentalists and business in the marketing of green products. Journal of Applied Behavioral Science, 27(1), 65-90.

Winston, M. (2002). NGO strategies for promoting corporate social responsibility. Ethics and International Affairs, 16(1), 71-87.

WWF, \& Lafarge. (2005a). Key achievements of the partnership. Retrieved 10 January, 2008, from www.panda.org/news_facts/newsroom/index.cfm?uNewsID=21313\&uLangID=1. WWF, \& Lafarge. (2005b). WWF-Lafarge. New Ambitions for the partnership. Retrieved 10 January, 2008, from www.panda.org/news_facts/newsroom/index.cfm?uNewsID=21313\&uLangID=1 . WWF International (2004). For a living planet. Brochure.

WWF International. (2007). Cleaner, greener cotton. Impacts and better management practices. Retrieved 10 January, 2008, from http://awsassets.panda.org/downloads/cotton_for_printing_long_report.pdf. WWF UK (2006). WWF-UK's business and industry engagement policy. 
Yin, R. K. (1994). Case study research. Design and methods. Thousand Oaks, CA: Sage.

Zietsma, C., \& Winn, M. I. (2007). Building chains and directing flows: Strategies and tactics of mutual influence in stakeholder conflicts. Business \& Society, 47(1), 68-101.

\section{NOTES}

${ }^{\text {a }}$ This typology builds on—and integrates—previous classifications of collaborative strategies (Austin, 2000; Harris, 1992; Mendleson \& Polonsky, 1995; Stafford and Hartman, 1998; Westley \& Vredenburg, 1991).

${ }^{\mathrm{b}}$ For further information, see FSC Forest Stewardship Council (https://ic.fsc.org/) and SFI Sustainable Forestry Initiative (http://www.sfiprogram.org/). 


\section{APPENDIX}

Case Studies' Multiple Sources of Evidence

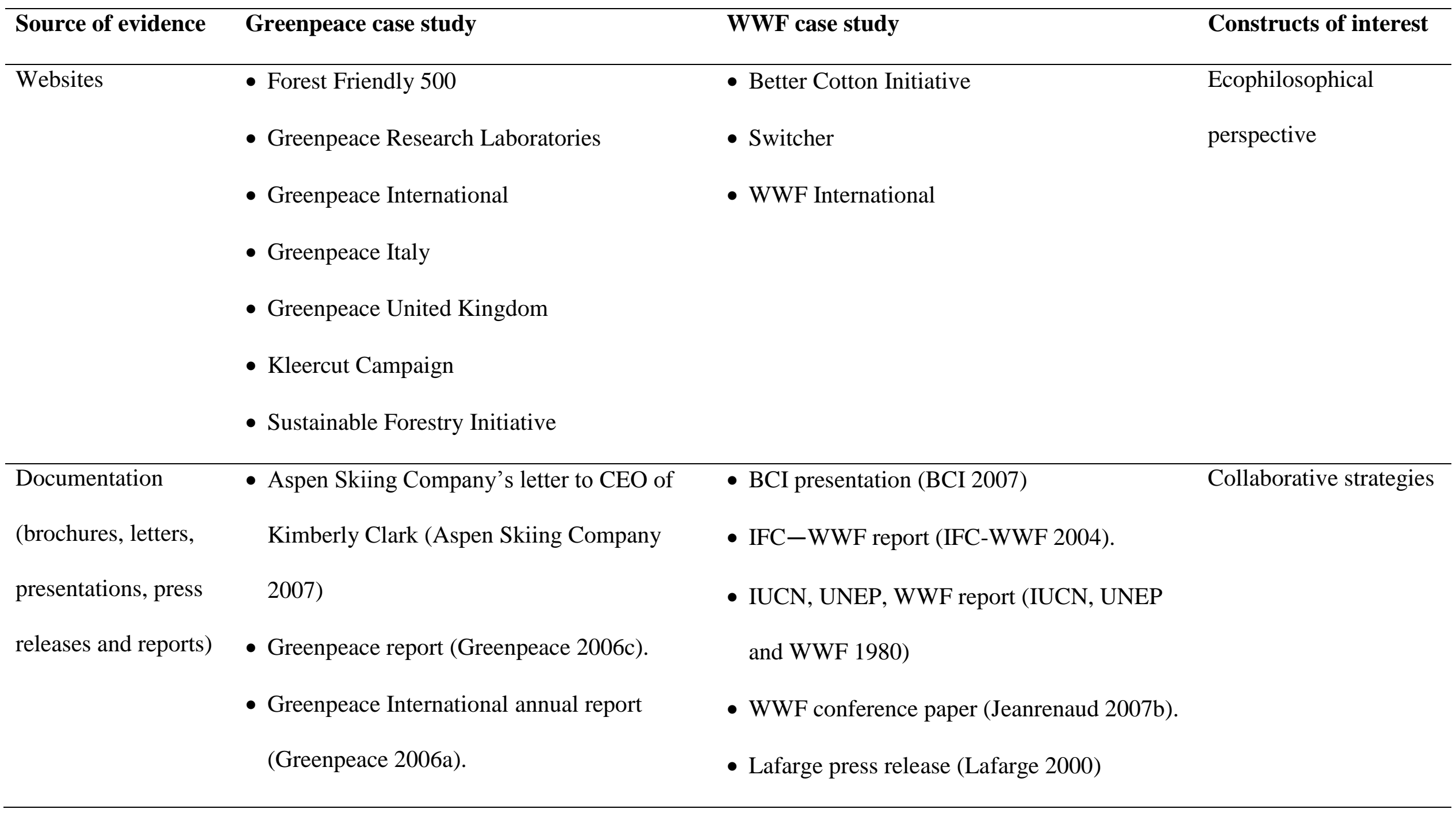


- Greenpeace position paper (Greenpeace 1997)

- Greenpeace press release (Greenpeace 2004)

- Greenpeace press release (Greenpeace 2006d)

- Greenpeace report (Greenpeace 2006b)

- Kimberly Clark report (Kimberly Clark 2005)
- Lafarge-WWF's brochure (Lafarge and

WWF 2011).

- WWF-Lafarge report (Lafarge and WWF 2005)

- WWF International brochure (WWF International 2004)

- WWF International report (WWF International 2007).

- WWF-Lafarge press release (WWF and Lafarge 2005a)

- WWF-Lafarge press release (WWF and Lafarge 2005b)

- WWF-UK's engagement policy (WWF UK 2006) 


\begin{tabular}{|c|c|c|c|}
\hline Interviews & $\begin{array}{l}\text { - Lindsey Allen (Forest Campaigner, } \\
\text { Greenpeace USA), } 14 \text { December } 2007 \text {, } \\
\text { telephone interview (about } 30 \text { minutes, fully } \\
\text { transcribed and checked by the interviewee) } \\
\text { - Wolfgang Lohbeck (Climate Expert and } \\
\text { Manager of Special Projects, Greenpeace } \\
\text { Germany), } 18 \text { December } 2007 \text {, telephone } \\
\text { interview (about } 1 \text { hour, transcribed and } \\
\text { checked by the interviewee) }\end{array}$ & $\begin{array}{l}\text { - Senior Manager Corporate Marketing, WWF } \\
\text { Switzerland, } 15 \text { January 2008, face-to-face } \\
\text { interview (about } 1 \text { hour } 30 \text { minutes, } \\
\text { transcribed and checked by the interviewee) } \\
\text { - Manager Corporate Marketing, WWF } \\
\text { International, } 30 \text { November 2007, telephone } \\
\text { interview (about } 30 \text { minutes) } \\
\text { - Lise Melvin (BCI Manager), } 11 \text { January } \\
\text { 2008, telephone interview (about } 1 \text { hour, } \\
\text { transcribed and checked by the interviewee) }\end{array}$ & $\begin{array}{l}\text { Factors driving the } \\
\text { selection of } \\
\text { collaborative strategies } \\
\text { (ecophilosophical and } \\
\text { contextual) }\end{array}$ \\
\hline Newspaper articles & Newspaper article: Canada Newswire (2006) & - Interview to Jean-Paul Jeanren & Contextual factors \\
\hline $\begin{array}{l}\text { and publicly } \\
\text { available interviews }\end{array}$ & $\begin{array}{l}\text { - Newspaper article: Canada Newswire (2007) } \\
\text { - Newspaper article: Houlder (2000) }\end{array}$ & $\begin{array}{l}\text { Relations Director, WWF International } \\
\text { (Jeanrenaud 2007a) }\end{array}$ & Corporate perspective \\
\hline Case studies and & - Journal paper: Elliott and Schlaepfer (2001) & - Journal paper: Giraud-Guigues, Jeanrenaud & Complementary \\
\hline scientific & - Case study: Lohbeck (2004) & and McIntosh (2004) & information on all \\
\hline publications & - Journal paper: Stafford et al. (2000). & - Conference paper: Heimer, Pudney, & constructs \\
\hline
\end{tabular}


Jeanrenaud, Giraud-Guigues and Picard

(2006)

- Journal paper: Jeanrenaud and Boulos (2003)

- Journal paper: Jeanrenaud and Boulos (2005) 


\section{FIGURE 1}

Environmental organizations' collaborative strategies for corporate engagement

\section{Collaboration Intensity}

Low

\begin{tabular}{ccccc}
\hline & & & \\
Strategic & Stakeholder & Marketing & Task Force or & Systems \\
Bridging & Approach & Agreements & Roundtable & Alliance \\
preliminary & instrumental & transactional & consultative & transformational \\
collaboration & collaboration & collaboration & collaboration & collaboration
\end{tabular}




\section{TABLE I}

Examples of Greenpeace's Engagement Strategies

\begin{tabular}{llll}
\hline Greenpace Unit & Engagement & Example & Corporate \\
& Strategy & & Time Frame \\
\hline Germany & Strategic Bridging & Greenfreeze Campaign: Ratified in 1987, the & Foron AG \\
& Montreal Protocol mandated the elimination of \\
& chlorofluorocarbons by the end of 1990s. \\
& Greenpeace Germany launched the Greenfreeze \\
& Campaign to bridge the Protocol's vision to the \\
& refrigeration industry. As part of its Campaign, \\
& Greenpeace joined forces with Foron (systems \\
& alliance) to develop the first Greenfreeze, an \\
& ecologically safe coolant based on a butane-propane \\
mixture.
\end{tabular}




\begin{tabular}{|c|c|c|c|c|}
\hline Canada-USA & $\begin{array}{l}\text { Stakeholder } \\
\text { Approach }\end{array}$ & $\begin{array}{l}\text { Kleercut Campaign: Greenpeace launched an } \\
\text { international campaign against Kimberly Clark, the } \\
\text { world's largest tissue paper company and holder of } \\
\text { brands such as Kleenex, Scottex, and Cottonelle. } \\
\text { Kimberly Clark was targeted for clearcutting } \\
\text { ancient rainforests, including Canada's Boreal } \\
\text { Forest. In its campaign, Greenpeace enlisted about } \\
650 \text { allies among corporate clients and shareholders } \\
\text { of Kimberly Clark. }\end{array}$ & 650 companies & 2004-2009 \\
\hline International Unit & $\begin{array}{l}\text { Product Licensing } \\
\text { and Endorsement }\end{array}$ & $\begin{array}{l}\text { Green Catalogues: Greenpeace licenses a } \\
\text { manufacturing company, Cafépress, to produce gifts } \\
\text { with the Greenpeace logo. On every product sold } \\
\text { online, Greenpeace receives about } 20 \% \text { of the } \\
\text { purchase price from Cafépress. }\end{array}$ & CaféPress & ... - present \\
\hline
\end{tabular}




\section{TABLE II}

Examples of WWF's Engagement Strategies

\begin{tabular}{|c|c|c|c|c|}
\hline WWF Unit & $\begin{array}{l}\text { Engagement } \\
\text { Strategy }\end{array}$ & Example & $\begin{array}{l}\text { Corporate } \\
\text { Counterparts }\end{array}$ & Time Frame \\
\hline International Unit & Product Licensing & $\begin{array}{l}\text { Switcher's Panda Collection: Switcher, a textile } \\
\text { company based in Lausanne, Switzerland, } \\
\text { approached WWF to market a sustainable clothing } \\
\text { line bearing the panda logo. While agreeing on } \\
\text { product licensing, WWF requested use of organic } \\
\text { cotton, and continuously pushed Switcher to } \\
\text { increase the sustainability of its operations. }\end{array}$ & Switcher & $2002-2008$ \\
\hline International Unit & $\begin{array}{l}\text { Multistakeholder } \\
\text { Roundtable }\end{array}$ & $\begin{array}{l}\text { Better Cotton Initiative: After a three-year } \\
\text { consultation process (2004-2007) with multiple } \\
\text { stakeholders along the cotton chain, WWF } \\
\text { constituted the Better Cotton Initiative (BCI) to }\end{array}$ & $\begin{array}{l}\text { Adidas, Gap, H\&M, } \\
\text { Ikea }\end{array}$ & 2007 - present \\
\hline
\end{tabular}


define principles for sustainable cotton cultivation.

Besides nonprofit and governmental organizations,

BCI's steering committee comprises four global

cotton buyers such as Adidas, Gap, H\&M and Ikea.

After formulating global criteria, BCI set up

regional working groups to develop implementation

strategies. At the end of 2012, noticeable volumes

of sustainable cotton were available on the market.

International Unit Systems Alliance

Lafarge Conservation Partnership:

Lafarge

2000 - present

Lafarge, world leader in construction materials, was

the first industrial group to become a WWF

Conservation Partner. The partners have met

ambitious targets in terms of reducing $\mathrm{CO} 2$

emissions; and are currently tackling new

challenges in the domains of persistent pollutants,

biodiversity restoration, and sustainable building. 
Still the partnership involved confrontation and

tension around Lafarge's project to realize an

aggregate superquarry at the heart of Mount

Roineabhal in South Harris, Scotland. 